\title{
PROBLEMATIKA CARA MEMAHAMI HADIS AKHIR ZAMAN DALAM PANDANGAN AHL AL-SUNNAH WA AL-JAM A', AH
}

\author{
Misbahuddin ${ }^{1}$ \\ ${ }^{1}$ Sekolah Pascasarjana UIN Syarif Hidayatullah Jakarta \\ Tangerang Selatan, Banten, Indonesia \\ misbahuddin_la@yahoo.com
}

\begin{abstract}
Abstrak:
Hadis-hadis akhir zaman sedikit berbeda dengan hadis lainnya, karena bersifat prediktif dan belum bisa dipastikan kapan terjadinya. Tema terkait hadis akhir zaman seperti kemunculan al-Mahdi, Dajjal, Isa, dan Perang Besar menyita banyak ulama untuk menginterpretasikanya. Terkadang, penafsiran tertentu memiliki tendensi yang bias kepentingan. Ada banyak perdebatan terkait hadishadis tersebut, misalnya apakah diterima hadis ahad dan hadis israiliyyat tentang akhir zaman? Ulama Sunni memilih untuk menggunakan hadis ahad dan berhati-hati menyikapi israiliyyat. Mereka juga menawarkan beberapa tahapan dalam merumuskannya.
\end{abstract}

Kata Kunci: Akhir Zaman, Hadis Ahad, Israiliyyat, Rekonstruksi.

\begin{abstract}
:
The end-time traditions differ slightly from other traditions because they are predictive and cannot be ascertained when they occur. Themes related to end-time hadiths such as the appearance of al-Mahdi, the Antichrist, Jesus, and the Great War seized many Muslim scholars to interpret them. Sometimes, certain interpretations have tendencies that are biased. There are a lot of debates related to these traditions, for example, are the traditions of ahad and israiliyyat about the end of time accepted? Sunni clerics choose to use ahad and be careful in responding to israiliyyat. They also offer several stages in formulating it.
\end{abstract}

Keywords: The End, Ahad Hadith, Israiliyyat, Reconstruction. 


\section{Pendahuluan}

Perbincangan mengenai hadis-hadis malhamah (bentuk tunggal dari malāhim yang berarti perang besar) telah banyak dilakukan oleh ulama-ulama dahulu maupun saat ini. Hanya saja, pola yang digunakan tidaklah sama. Para pengumpul hadis seperti Imam al-Bukhārī melakukannya secara parsial, begitu juga Imam Muslim serta sebagian imam hadis lain hanya meriwayatkan beberapa saja dari yang mereka miliki. Seperti Imam Bukhārī, imam Muslim dan lainnya memasukkan pembahasan al-fitan pada bab- bab akhir kitabnya. ${ }^{1}$

Adapula yang hanya menghimpun hadis-hadis terkait fitnah dan perang besar dengan model penulisan yang berbeda dengan al-Jāmi' atau al-Sunan, seperti Kitāb al-Fitan karya Nu'aim bin Hammād al-Marwazī (w. 228 H), alSunan al-Wāridah fì al-Fitan wa Ghawāiluhā wa al-Sā'ah wa Ashrātuhā karya Abū 'Amr 'Utsmān al-Dānī (w. 444 H), al-Nihāyah fì al-Fitan wa al-Malāhim karya Ibn Katsīr (w. 774 H), Kitāb al-Qanā'ah fì Mã Yuḥsan al-Ihāțah bihì min Asyrāt al-Sā'ah karya al-Sakhāwī (w. 902 H). Beberapa kitab di atas ditulis secara khusus dan hanya memuat hadis-hadis akhir zaman saja. Kitab-kitab tersebut lebih spesifik menyoal hadis-hadis akhir zaman dibandingkan dengan kitab alJāmi' maupun al-Sunan karena pada dasarnya berbeda dalam orientasi penulisannya.

Ulama kontemporer, Șalāḥ al-Dīn bin Aḥmad al-Idlibī banyak mengkritik hadis-hadis malhamah atau hadis-hadis akhir zaman secara umum dari sisi kualitas sanad. Ia menuliskan kritiknya dalam kitabnya Ahạdīth Fad̄äil al-Syām Dirāsah Naqdiyyah. Meski terkesan bahwa ia hanya berupaya mengkritik hadishadis Syam, namun hadis-hadis Syam juga termasuk bagian dari lokasi perang besar, dan banyak peristiwa akhir zaman. ${ }^{2}$ Banyak hadis-hadis terkait hal ini faktanya diriwayatkan oleh Ka'b al-Aḥbār, Wahb bin Munabbih dan lain sebagainya yang banyak meriwayatkan hadis-hadis Israiliyyat. Pendapat ini sebelumnya juga disampaikan oleh Rasyīd Riḍā dalam tafsir al-Manār. ${ }^{3}$

Penulisan sejarah dalam Islam pada dasarnya beragam, di antaranya ada yang hanya mengisahkan tentang sejarah hidup Rasulullah Saw dan kitab ini

${ }^{1}$ Lihat al-Bukhārī, Șahịh al-Bukhārī, juz 9 (Kairo: Dār al-Sya'b, 1407), 58; al-Tirmidzī, Sunan al-Tirmidz̄̄, juz 4 (Beirut: Dār Iḥyā’ al-Turās al-'Arab̄i, t.t.), 495; Ibn Mājah, Sunan Ibn Mājah, juz 5 (Maktabah Abi al-Ma'āṭ̂, t.t.), 81.

${ }^{2}$ Di antara kritik yang disampaikan berkaitan dengan hadis benteng terkuat umat Islam di akhir zaman adalah Syam yang diriwayatkan oleh Abu Dardā'.

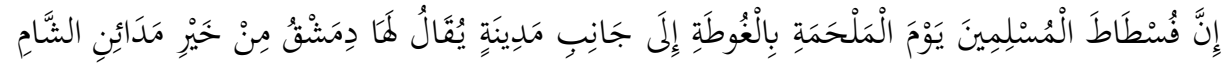

"Sesungguhnya barak kaum muslimin di hari perang besar terjadi berada di Ghauthah (nama sebuah daerah di Syam), sampai ke sisi sebuah kota yang dinamakan Damaskus, kota terbaik dari kota-kota yang ada di Syam." Lihat Șalāḥ al-Dīn al-Idlibī, Ahāàìth Faḍail al-Shām: Dirāsah al-Naqdiyyah (t.k: t.p, t.t.), 27-37.

${ }^{3}$ Muḥammad Rashīd Riḍā, Tafsìr al-Manār, juz 8 (Beirut: Dār Kutub al-Ilmiah, 1999), 210-211. 
masuk ke dalam kategori kitab sirrah, adapula sejarah yang hanya mencatat peperangan pada masa Rasul maupun sahabat dan orang-orang setelah mereka, kitab semacam ini masuk ke dalam kategori kitab maghāzi. ${ }^{4}$ Penulisan sejarah semacam ini berbeda dengan penulisan sejarah masa depan dalam potret malāhim, hal ini dikarenakan hadis-hadis dalam kitab-kitab sejarah telah berakhir periodesasinya. Tidak ada kemungkinan untuk merangkai kembali kisahkisahnya, meskipun tidak menutup kemungkinan beberapa peristiwa dalam sejarah tersebut masih akan didaur ulang bagian-bagiannya oleh umat Islam sepanjang sejarah.

Pembahasan tentang hadis-hadis akhir zaman terkesan digampangkan, dan layaknya melempar dadu jika melihat fenomena yang berkembang. HT atau Hizbut Tahrir misalnya, menggunakan dalil tentang khilafah merujuk kepada hadis-hadis prediktif tentang akan munculnya kekhilafahan sesudah Nabi Saw. Atau ISIS yang banyak ditemukan menggunakan hadis-hadis masa depan dalam majalah mereka. Seperti ISIS yang mengutip hadis yang bersumber dari Abī Dardā' tentang keberkahan negeri Syam sebagai benteng terkuat, ${ }^{5}$

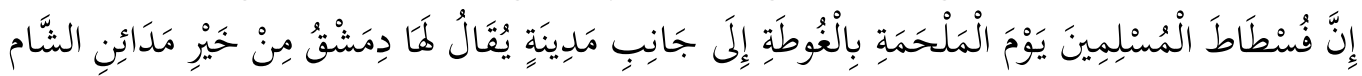

"Sesungguhnya barak kaum muslimin di hari perang besar terjadi berada di Ghauthah (nama sebuah daerah di Syam), sampai ke sisi sebuah kota yang dinamakan Damaskus, kota terbaik dari kota-kota yang ada di Syam." 6

Hadis ini dimaknai secara tendensius dalam majalah Dabiq untuk menguatkan posisi mereka di Syam. Hal ini juga sangat efektif untuk merekrut militan dari banyak negara untuk mau berhijrah dan berjihad di Syam. ${ }^{7}$ Pemaknaan hadis tersebut digeser untuk konteks kekinian yang menurut mereka benar dan sesuai.

Berawal dari latar belakang tersebut, kajian ini akan terfokus pada interpretasi dan rekonstruksi hadis akhir zaman, kemudian diambil contoh hadisnya untuk mengungkap status hadis-hadis tersebut, apakah bermasalah atau tidak. Namun sebelum masuk ke pembahasn, perlu adanya literature review. Abdillah tahun 2018, juga menulis artikel tentang tanda akhir zaman ditinjau dari segi hadits. Artikel dengan judul "Studi Kritik Melalui Metode Takhrij Hadits Tentang Menghias Bangunan Masjid Sebagai Tanda Akhir Zaman" hanya terfokus pada kasus menghias bangunan masjid sebagai tanda akhir zaman. ${ }^{8}$

4 'Abd al-'Azīz al-Daurā, Nasy'ah 'Ilm al-Tārīkh 'ind al- 'Arab (t.k: t.p, t.t), 22.

5 Majalah Dhabiq, "Panggilan untuk Hijrah versi bahasa Indonesia” (Edisi 3, 1435 Shawwal), 9 .

${ }^{6}$ Abū Dāwud Sulaimān al-Sijistānī, Sunan Abī Dāwud, juz 4 (Beirut: Dār al-Kitāb al'Arabī, t.t.), 185; lihat juga al-Ishbilī, al-Ahkām al-Syar'iyyah al-Kubra, juz 4 (Riyạ̣̄: Maktabah al-Rushd, 2001), 514.

${ }^{7}$ Majalah Dhabiq, Panggilan untuk Hijrah versi bahasa Indonesia, 31

8 Junaidi Abdillah, "Studi Kritik Melalui Metode Takhrij Hadits Tentang Menghias Bangunan Masjid Sebagai Tanda Akhir Zaman,” Jurnal Al Ijtimaiyyah 4, no. 1 (2018): 26-63. 
Dalam sudut pandang yang lain juga, Hadiyanto dan Khumairoh menulis dengan judul "Makna Simbolik Ayat-Ayat tentang Kiamat dan Kebangkitan dalam Alquran", namun tulisan ini terfokus pada ayat-ayat Al-Quran bukan hadis. ${ }^{9}$ Kemudian ada penelitian yang dilakukan oleh Muhammad Dliyauddin dengan judul "Hadith Prediktif Perang Melawan Bangsa "Ajam yang Bermata Sipit Sebagai Tanda Hari Kiamat", penelitian ini hanya terfokus pada kitab Shahih Bukhari saja. ${ }^{10}$ Dan literatur review yang terakhir dari Soleh bin Che' Had dengan judul "Penafsiran Ayat Tentang Hari Kiamat Menurut Umar Sulaiman 'Abdullah Al-Asyqar", kajian ini juga terfokus pada salah satu tokoh yaitu Umar Sulaiman "Abdullah Al-Asyqar dan penafsiran ayat, bukan dalam ranah hadis. ${ }^{11}$ Dari beberapa kajian pustaka tersebut, belum ada yang membahas problematika hadis akhir zaman dengan perspektif Ahlussunnah wal Jamā'ah.

\section{Metode}

Kajian ini termasuk penelitian kualitatif, yang kemudian dijelaskan dengan deskriptif-analitik. Kajian ini menggunakan sumber pustaka terkait hadis-hadis akhir zaman. Adapun tahapan uraiannya sebagai berikut. Pertama akan diuraikan problematika umum terkait hadis ahad dan hadis yang mengandung israilliyat, kemudian membahas bagaimana interpretasi dan rekonstruksi hadis-hadis tersebut dalam perspektif ahlus sunnah wal jamaah. Setelah itu diambil contoh pengaplikasian rekonstruksi hadis-hadis perang besar dan menjelaskan hadishadis yang bermasalah. Demikian uraian yang ada dalam kajian ini.

\section{Problematika Israiliyyat dan Hadis Ahad dalam Memahami Hadis Akhir Zaman Perspektif Ahlus Sunnah Wal Jamā'ah}

Dua sumber utama untuk merekonstruksi sejarah akhir zaman menurut Yāsir bin 'Abd al-Raḥmān' dalam tradisi Ahlus Sunnah wal Jamā'ah adalah Alquran dan Hadis. ${ }^{13}$ yang pertama bahwa hadis-hadis yang digunakan memiliki kualifikasi sahih atau paling tidak hasan. Hal ini disebabkan karena hadis-hadis tersebut digunakan untuk membangun sebuah gagasan tentang akidah, bukan saja

${ }^{9}$ Andy Hadiyanto dan Umi Khumairoh, "Makna Simbolik Ayat-Ayat tentang Kiamat dan Kebangkitan dalam Alquran," Indonesian Journal of Multidisciplinary Islamic Studies 2 no. 2 (2018): 187-212.

${ }^{10}$ Muhammad Dliyauddin, "Hadith Prediktif Perang Melawan Bangsa 'Ajam yang Bermata Sipit Sebagai Tanda Hari Kiamat” (Universitas Islam Negeri Sunan Ampel, 2018).

${ }^{11}$ Soleh bin Che' Had, "Penafsiran Ayat Tentang Hari Kiamat Menurut Umar Sulaiman "Abdullah Al-Asyqar,” (Universitas Islam Negeri Ar-Raniry, 2018).

${ }^{12}$ Ia menulis sebuah disertasi tentang hadis-hadis Malāhim. Disertasi tersebut ditulis di Universitas Umm al-Qurā, Mekah pada Fakultas Akidah dan Agama-agama pada tahun $1431 \mathrm{H}$ bertepatan dengan tahun $2009 \mathrm{M}$.

${ }^{13}$ Yāsir bin 'Abd al-Raḥmān al-Aḥmadī, Malāhim Ākhir al-Zamān (Riyadh: Maktabah Majallah al-Bayān, 1434 H), 53. 
tentang nasehat yang dengan menggunakan hadis-hadis dhaif pun tidak mengapa. ${ }^{14}$

Tidak sedikit hadis-hadis akhir zaman semacam ini bercampur dengan riwayat-riwayat isräiliyat. Ini menimbulkan banyak spekulasi yang muncul. Nama yang paling banyak muncul dalam riwayat-riwayat isra'iliyyat terkait hadis-hadis akhir zaman adalah Ka'ab al-Aḥbār dan Wahab ibn Munabbih. Mau tidak mau hal ini menimbulkan kecurigaan yang harus disikapi, dan tentu saja sedikit banyak merubah persepsi tentang hadis-hadis tersebut. Al-Idlibī menyebut bahwa Ka'ab al-Aḥbār yang memiliki nama lengkap Ka'b bin Māti' al-Hịmyari telah meriwayatkan banyak sekali hadis-hadis Syam, ${ }^{15}$ ia sendiri adalah orang Yahudi yang memeluk Islam pada masa 'Umar bin al-Khațāa dan meninggal pada tahun $32 \mathrm{H}$ pada masa kekhalifahan 'Uthmān bin 'Affān. ${ }^{16}$ Pada masanya, $\mathrm{Ka}$ 'ab seringkali menceritakan kisah-kisah isra'iliyyat kepada para sahabat Nabi, demikian pula ia banyak mengambil hadis dari para sahabat Nabi. ${ }^{17}$ Bagi Ṭahā Jābir persinggungan antara Islam dan Ahli Kitab sudah ada sejak dahulu, ceritacerita tentang kisah-kisah israiliyyat sudah banyak didengar secara turun temurun dari semenjak dahulu, hal ini sangat memungkinkan hadis-hadis tersebut terutama berkaitan dengan akhir zaman bercampur dengan kisah-kisah isra'iliyyat. Salah satu sahabat nabi yang diklaim banyak meriwayatkan keterangan-keterangan isra'iliyyat adalah 'Abdullāh ibn 'Abbās. ${ }^{18}$

Menurut Yāsir adakalanya sumber-sumber isra'iliyyat itu diterima, ditolak, adapula yang didiamkan saja, tidak didustakan juga tidak dibenarkan. ${ }^{19}$ Beritaberita isra'iliyyat diterima manakala ia sesuai dengan sumber utama umat Islam, yakni Alquran dan Sunah yang sahih. Sebaliknya isra'iliyyat ditolak atau tidak diterima ketika ia bertentangan dengan Alquran dan Hadis yang sahih. Dalam hal ini seperti kisah dalam perang besar yang terjadi di akhir zaman, menurut sumber mereka, orang-orang Yahudi, kemenangan saat itu diraih orang Yahudi dan

\footnotetext{
${ }^{14}$ Maḥmūd al-Ṭaḥhān, Taisīr Muștalah al-Hadīth (Beirut: Dār al-Fikr, t.t.), 54.

${ }^{15} \mathrm{Di}$ antara hadis-hadis Syam yang ia riwayatkan adalah sebagaimana berikut:

وروي عن كعب أنه قال: أحب البلاد إلى الله تعالى الشام، وأحب الشام إلى الله تعالى القدس، وأحب القدس إلى الله تعالى جبل نابلس
}

Diriwayatkan dari Ka'b, ia mengatakan: "Negeri yang paling dicintai oleh Allah adalah Syam, dan daerah Syam yang paling dicintai oleh Allah adalah al-Quds (Palestina), dan bagian alQuds yang sangat dicintai Allah adalah gunung Nabulsi." Lihat Șalạ̣̄ al-Dīn al-Idlibī, Aḥādīth Faḍāil al-Shām: Dirāsah al-Naqdiyyah, 88.

${ }^{16}$ Șalāḥ al-Dīn al-Idlibī, Ahạdīth Fậāil al-Shām: Dirāsah al-Naqdiyyah, 91.

${ }^{17}$ Shams al-Dīn al-Dzahabī, Siyar A'lām al-Nubalā', juz 3 (Beirut: Muassasah alRisālah, 1405), 489.

18 Ṭahā Jābir al-'Alwān̄i, Ishkāliyyat al-Ta'āmul Ma'a al-Sunnah al-Nabawiyyah (Virginia: al-Ma'had al-‘ālami li al-Fikr al-Islāmī, 2014), 226.

${ }^{19}$ Yāsir bin 'Abd al-Raḥmān al-Aḥmadī, Malāḥim Ākhir al-Zamān, 76-78. 
Nasrani, dan 'Isa As akan turun untuk memenangkan mereka. Semua ini tentu saja bertolak belakang dengan narasi yang ada dalam Alquran maupun Hadis. ${ }^{20}$

Namun manakala berita-berita isra'iliyyat tersebut tidak bertentangan dengan Alquran maupun Hadis, belum pula ditemukan kesesuaiannnya dengan realita, baik yang menolak ataupun yang menerima, maka sikap yang perlu diambil adalah tengah-tengah antara tidak membenarkan juga tidak mendustakannya. Fakta semacam ini juga ada dalam kisah yang terdapat dalam sumber israiliyyat, bahwa orang-orang Yahudi di akhir zaman akan berkumpul di Palestina kemudian mendirikan negara, di sana mereka akan menerima kemurkaan dari Allah SWT. ${ }^{21}$ Keterangan ini dapat dirujuk di dalam kitab alamānāt wa al- 'i'tiqādāt, dari sini tidak ada keterangan Alquran maupun hadis yang mengonfirmasi penjelasan semacam itu. Dengan demikian, sikap yang perlu diambil adalah tidak perlu mendustakannnya maupun membenarkannya.

Persoalan lain yang muncul adalah penggunaan hadis ahad yang dipertentangkan oleh beberapa sarjana muslim karena hadis ahad dianggap tidak cukup kuat untuk dijadikan hujah dalam menetapkan sebuah konsepsi akidah. Hadis ahad hanya sampai kepada derajat dhann atau sangkaan dan tidak sampai kepada taraf yakin. Hadis model ini hanya bisa digunakan sebagai dalil hukum tidak lebih dari itu, tidak sampai kepada persoalan akidah ataupun hal-hal ghaib. ${ }^{22}$ Salah satu yang memiliki pemikiran semacam ini adalah Muhammad Abduh, yang pernah menafsirkan salah satu firman Allah SWT, sebagaimana yang ditulis oleh Rashīd Riḍā, sebagai berikut:

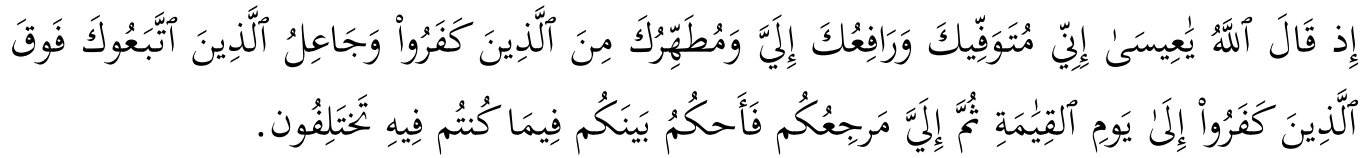

"(Ingatlah), ketika Allah berfirman: "Hai Isa, sesungguhnya Aku akan menyampaikan kamu kepada akhir ajalmu dan mengangkat kamu kepadaKu serta membersihkan kamu dari orang-orang yang kafir, dan menjadikan orang-orang yang mengikuti kamu di atas orang-orang yang kafir hingga hari kiamat. Kemudian hanya kepada Akulah kembalimu, lalu Aku memutuskan diantaramu tentang hal-hal yang selalu kamu berselisih padanya" 23

Menurut Muhammad 'Abduh, hadis yang berbicara tentang diangkat dan diturunkannya 'Isa As adalah hadis ahad yang berhubungan dengan persoalan keyakinan karena ia berhubungan dengan hal ghaib, hal ini tidak bisa diterima karena keyakinan tidak bisa dibangun di atas sesuatu selain yang qat' $\bar{\imath}$. Pendapat

${ }^{20}$ Yāsir bin 'Abd al-Raḥmān al-Aḥmadī, Malāḥim Ākhir al-Zamān, 77

${ }^{21}$ Yāsir bin 'Abd al-Raḥmān al-Aḥmadī, Malāḥim Ākhir al-Zamān, 78

${ }^{22} \mathrm{Abū}$ 'Amr al-Dānī, al-Sunan al-Wāridah fì al-Fitan wa Ghawā'iluhā wa al-Sā' ah wa Ashrātuhā, ed. Riḍā Allāh al-Mubārakfurī (t.k: Dār al- ‘āṣimah, t.t.), 37

${ }^{23}$ QS. Āli 'Imrān: 55 
semacam ini juga pernah dilontarkan oleh Mahmūd Shaltūt. ${ }^{24}$ Argumentasi seperti ini memiliki banyak kelemahan di antaranya adalah bahwa ternyata para sahabat semenjak dahulu memercayai awal mula penciptaan, berita-berita akhir zaman, atau sifat-sifat Allah. Persoalan-persoalan tersebut nyatanya banyak sekali bersumber dari hadis-hadis ahad, jika hal tersebut tidak memiliki implikasi akidah, maka seharusnya keyakinan semacam itu tidak sampai kepada kita saat ini. ${ }^{25}$ Dalam ilmu hadis sunni sendiri, pada dasarnya hadis yang tidak memiliki kekuatan hukum untuk menjadi dalil bagi persoalan akidah dan syariat adalah hadis-hadis dhaif dan palsu, selain itu, hadis-hadis yang maqbūl (diterima) masih bisa digunakan untuk melegitimasi persoalan akidah dan hukum. ${ }^{26}$

\section{Interpretasi dan Rekonstruksi Hadis Akhir Zaman Dalam Pandangan Ahlus Sunnah wal Jamā'ah.}

Terdapat beberapa persyaratan yang dijelaskan oleh Yāsin bin 'Abd alRaḥmān terkait bagaimana menafsirkan teks-teks sumber tersebut khususnya teks-teks hadis. ${ }^{27}$

Pertama, menghimpun semua teks terkait dengan kejadia yang akan datang tanpa terkecuali.

mengumpulkan seluruh teks-teks yang berkaitan dengan suatu peristiwa yang akan terjadi tanpa pengecualian. Yūsuf al-Qaraḍāwī berpandangan jika menghimpun semua teks bertema serupa bertujuan guna menjelaskan hadis mutasyäbih (yang samar) menggunakan hadis muhkam (jelas), yang umum bisa dijelaskan melalui hadis yang khusus, hadis mutlak terbatasi dengan hadis muqayyad, maka akan menghasilkan pemahaman utuh. ${ }^{28}$

Kedua, tak menafsirkan terlampau jauh dari teks asli, tak merubah apalagi mengganti dengan lainnya. Ole karena itu, mengganti terminologi di luar maknanya akan berpengaruh signifikan serta mesti memiliki sikap berhati-hati. ${ }^{29}$

Ketiga, menguasai teks-teks sumber asli (berbahasa Arab) dan konteks yang dibicarakan dalam teks tersebut. Bagi umat muslim, kedudukan Bahasa Arab memang penting, baik untuk komunikasi dalam konteks internasional maupun pemahaman keagamaan yang paripurna. ${ }^{30}$

${ }^{24}$ Abū 'Amr al-Dānī, al-Sunan al-Wāridah fì al-Fitan wa Ghawā'iluhā wa al-Sā'ah wa Ashrātuhā, ed. Rị̣ā Allāh al-Mubārakfurī, 37.

${ }^{25} \mathrm{Abū}$ 'Amr al-Dān̄̄, al-Sunan al-Wāridah fì al-Fitan wa Ghawā'iluhā wa al-Sā'ah wa Ashrāṭhā, ed. Rị̣ā Allāh al-Mubārakfurī, 42.

${ }^{26}$ Maḥmūd al-Ṭaḥhān, Taisīr Muștalaḥ al-Hadīth, 54.

${ }^{27}$ Yāsir bin 'Abd al-Raḥmān al-Aḥmad̄̄, Malāhim Ākhir al-Zamā, 59-64

${ }^{28}$ Yūsuf al-Qarḍ̄̄̄ī, Kaifa Nata' 'àmal ma'a al-Sunnah al-Nabawiyyah (Kairo: Dār alSyurūq, 2004), 125.

${ }^{29}$ Yāsir bin 'Abd al-Raḥmān al-Aḥmadī, Malāḥim Ākhir al-Zamān, 60

${ }^{30}$ Akhiril Pane, "Urgensi Bahasa Arab; Bahasa Arab Sebagai Alat Komunikasi Agama Islam," Komunikologi 2, no.1 (2018): 77-88. 
Keempat, merujuk penafsiran teks pada sahabat, tabiin, serta ulama salaf.

Kelima, memastikan teks sesuai dengan makna tekstualnya serta boleh menginterpretasikannya jika hanya ada qarinah lainnya yang ditunjukkan.

Keenam, mengembalikan sumber-sumber yang kurang jelas, samar (mutasyābih) kepada sumber-sumber yang pasti (muhkam), atau meminta fatwa orang yang lebih paham.

Ketujuh, berita (ikhbār) dan pensyariatan (tasyrī') harus dibedakan. Langkah ini memiliki konsekuensi bahwa hadis-hadis akhir zaman tidak bisa digolongkan kepada hukum halal-haram karena ia memang tidak memiliki konsekuensi hukum.

Meskipun sumber rujukannya sama, antara sìrah dan maghāzì dengan malāhnim yakni riwayat-riwayat hadis dan Alquran, demikian pula atsar para sahabat namun cara memperlakukan dua kategori tersebut tidaklah sama. Baik sìrah dan maghāzì memiliki periodesasi yang telah usai diperbincangkan. Ia tidak lagi memiliki konsekuensi seserius hadis-hadis malāhim. Ulama telah selesai menyusun banyak kitab seperti Sīrah Ibn Isḥāq, Sìrah Ibn Hishām, al-Maghāzī karya al-Wāqidī, dan lain sebagainya. Yang terjadi selanjutnya dalam sejarah perang maupun sejarah perjalanan Nabi adalah mengambil hikmah, atau jika ada yang berkaitan dengan syariat maka dirumuskanlah skema pensyariatannya.

Sejarah atau histori berasal dari kata benda Yunani "istoria" yang berarti pemaparan tentang tanda-tanda, terutama tentang manusia dalam urutan kronologis. Menurut Badri Yatim, sejarah dalam definisinya yang paling umum adalah masa lampau umat manusia. ${ }^{31}$ Ketika sejarah dianggap sebagai kejadian di masa lampau, maka bagi Taufik Abdullah ia memiliki empat batasan. Pertama adalah dimensi waktu; kedua adalah pembatasan yang menyangkut peristiwa, menurutnya tidak semua peristiwa di masa lalu dipandang sebagai sebagai sejarah, hal ini merupakan kecenderungan umum yang diikuti oleh sejarawan-; ketiga, pembatasan yang menyangkut tempat, -sejarah seharusnya diartikan sebagai tindakan manusia dalam jangka waktu tertentu pada masa tertentu pada masa lampau di tempat tertentu-; dan keempat, pembatasan yang berkaitan dengan seleksi, peristiwa-peristiwa dalam sejarah bisa dikatakan sebagai sejarah jika ia bisa dikaitkan dengan dalam satu konteks historis yakni ketika kepingankepingan peristiwa menjadi satu-kesatuan proses atau dinamika yang menjadi perhatian sejarawan. Dengan kata lain menurut Taufik, sejarah adalah gambaran masa lampau dalam karya para sejarawan. ${ }^{32}$

Pengertian sejarah dalam pandangan Taufik di atas, memberikan sedikit ruang bagi kejadian-kejadian yang akan datang di akhir zaman sebagai "sejarah

${ }^{31}$ Badri Yatim, Perkembangan Historiografi Islam (Ciputat: Lembaga Penelitian UIN Jakarta, 2009), 1.

${ }^{32}$ Badri Yatim, Perkembangan Historiografi Islam, 1, bandingkan dengan Taufik Abdullah dan Abdurrachman Surjomihardjo (Ed.), Ilmu Sejarah dan Historiografi: Arah dan Perspektif (Jakarta: PT Gramedia, 1985), x-xii. 
masa depan", mengapa demikian? Karena sumber-sumber akhir zaman memiliki dimensi waktu, pembatasan terkait peristiwa, pembatasan tempat dan pembatasan berkaitan dengan seleksi. Namun, untuk menolak berita-berita akhir zaman semacam ini juga bisa dilakukan karena sejarah dalam pengertian Badri Yatim adalah masa lampau umat manusia sedangkan sumber-sumber akhir zaman hanya semacam prediksi dan belum tentu kebenaran peristiwanya terjadi.

Meskipun dikatakan sama dan beda di satu waktu, menurut Yāsir, beritaberita akhir zaman perlu diposisikan oleh umat Islam dengan tepat. Hal ini disebabkan karena teks-teks akhir zaman khususnya al-malähim memiliki konsekuensi untuk ditarik ke sana kemari. Ketertarikan untuk mencocokcocokkan setiap peristiwa yang akan terjadi menjadi daya tarik tersendiri bagi siapapun, khususnya umat Islam. Untuk itu, menurut Yāsir dalam kaitannya dengan fenomena yang aktual terjadi, ada banyak hal yang perlu dijadikan barometer dalam pandangan ahlussunnah wa al-jamaah menyikapi berita-berita akhir zaman. Pertama, adalah memastikan dengan benar kesesuaian antara yang terjadi dengan sumber-sumber yang ada; Kedua, tidak terburu-buru dalam mengambil keputusan dan yang ketiga memperhatikan hal-hal penting dalam menerapkan hadis-hadis akhir zaman dengan fenomena yang ada. Ini seperti memperhatikan urutan waktu kejadian, memperhatikan maslahat dan mafsadahnya, dan mengembalikan persoalan tersebut kepada orang yang memahaminya. ${ }^{33} \mathrm{Hal}$ ini tergambar dari kisah Ibn Șayyād yang diduga memiliki kemiripan dengan Dajjal sebagaimana dalam hadis Muḥammad bin al-Munkadir berikut. $^{34}$

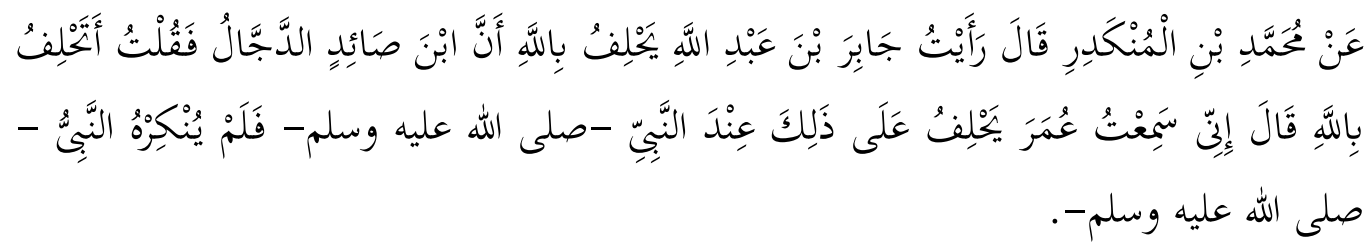

"Aku melihat Jābir bin 'Abdillāh bersumpah atas nama Allah bahwa Ibn Șā'id adalah Dajjāl, maka aku berkata: "Apakah kamu bersumpah dengan nama Allah?" "Kemudian Jābir mengatakan bahwa ia mendengar 'Umar bersumpah dengan hal itu di sisi Nabi Saw, dan beliau tidak mengingkarinya."

Meskipun Rasulullah tidak mengingkari bahwa Ibn Șayyād memiliki ciriciri sebagaimana Dajjal namun beliau tidak terburu-buru untuk mempercayainya. Hal ini terbukti bahwa ternyata ia bukan Dajjal yang dimaksud. ${ }^{35}$

\footnotetext{
${ }^{33}$ Yāsir bin 'Abd al-Raḥmān al-Aḥmadī, Malāḥim Ākhir al-Zamān, 69

${ }^{34}$ Muslim bin al-Ḥajjāj, Șaḥ̄h Muslim, juz 8 (Beirut: Dār al-Jail, t.t.), 192.

${ }^{35}$ Yāsir bin 'Abd al-Raḥmān al-Aḥmadī, Malāhim Ākhir al-Zamān, 67
} 


\section{Rekonstruksi Hadis-Hadis Perang Besar (Malhamah Kubra)}

Dengan berpijak kepada beberapa konsepsi dalam merekonstruksi hadishadis akhir zaman di atas, Yāsir memberikan gambaran kronologis pra perang besar terjadi, ketika perang besar terjadi dan pasca perang besar terjadi. ${ }^{36}$ Ini dimulai dengan kekacauan yang terjadi di dunia, kemudian muncul al-Mahdi, pembangunan Baitul Maqdis dan kehancuran Madinah. ${ }^{37}$

Hadis-hadis tentang al-Mahdī terbilang sangat banyak, mulai dari ciri-ciri fisiknya, namanya, sifat-sifatnya, tanda-tanda kemunculannya, tempat keluarnya dan banyak lagi yang lainnya.

Sebelum al-Mahdī keluar beberapa hadis menyebut bahwa akan banyak kezaliman dan kelaliman yang terjadi, baru kemudian al-Mahdī keluar untuk menuntaskan persoalan tersebut. Hal ini didasarkan kepada riwayat yang bersumber dari Musnad Aḥmad, Șạ̣iḥ Ibn Hịbbān, Musnad Abī Ya'la dan lain sebagainya. Kualitas hadis ini menurut Syu'aib al-Arnaut juga tergolong sahih sesuai dengan syarat yang ditetapkan oleh syaikhain.

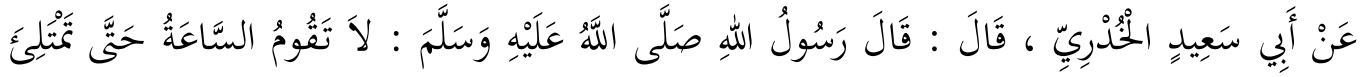

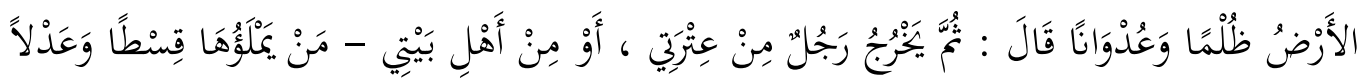
، كَمَا مُلِيَتْت ظُلْمَا وَعُدْوَانَا.

"Dari Abu Sa'̄̄d al-Khudrī, Rasulullah Saw bersabda: "Hari kiamat tidak akan terjadi sampai bumi akan penuh dengan kezaliman dan permusuhan: lalu akan keluar dari keturunanku atau dari ahli baitku yang akan mengisi dunia ini dengan keadilan, sebagaimana dulunya diisi dengan kezaliman dan permusuhan." 38

Situasi selanjutnya yang akan muncul sebagaimana kesimpulan yang diperoleh Yāsir adalah akan dibangunnya Baitul Maqdis dan akan hancur atau robohnya Yatsrib. Ini didasarkan kepada riwayat Mu'āz bin Jabal.

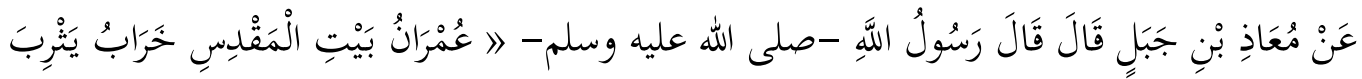

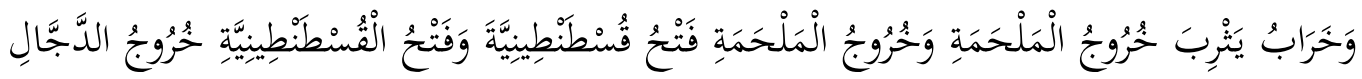

'Dari Mu'āz bin Jabal berkata: Rasulullah Saw bersabda: "Makmurnya Baitul Maqdis, kehancuran Yatsrib, dan kehancuran Yatsrib munculnya

\footnotetext{
${ }^{36}$ Yāsir bin 'Abd al-Raḥmān al-Aḥmadī, Malāhim Ākhir al-Zamān, 167

${ }^{37}$ Yāsir bin 'Abd al-Raḥmān al-Aḥmadī, Malāḥim Ākhir al-Zamān, 184

${ }^{38}$ Aḥmad bin Hanbal, Musnad Aḥmad, juz 3 (Beirut: 'Ālam al-Kutub, 1419), 36.
} 
perang besar, munculnya perang besar kemenangan atas Konstantinopel, kemenangan atas Konstantinopel tanda keluarnya Dajjal." 39

Menurut Yāsir kemenangan atas Konstatinopel yang pernah diraih oleh umat Islam tidak menunjukkan atas batalnya riwayat di atas. Hal itu disebabkan karena fenomena yang ada bersifat parsial. Tidak ada tanda-tanda yang lain yang muncul seperti munculnya al-Mahdī, kehancuran Yatsrib dan lain sebagainya. Dengan demikian, menurut Yāsir akan ada kemenangan atas Konstantinopel untuk kedua kalinya.

Tahapan selanjutnya adalah munculnya perpecahan antara orang-orang muslim dan nasrani yang menyebabkan perang besar yang dijanjikan. Sebagaimana yang diriwayatkan oleh Imam Muslim dari Abū Hurairah.

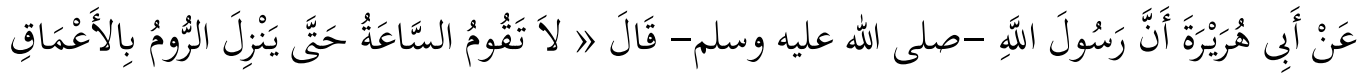

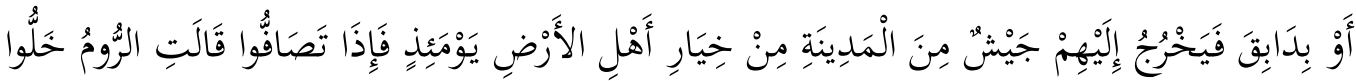

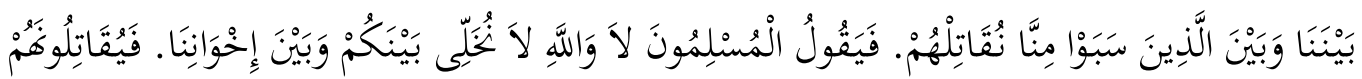

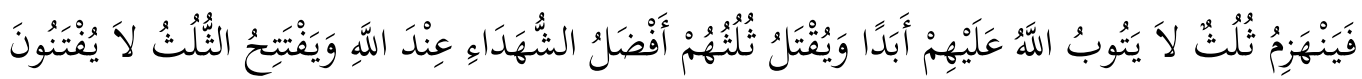

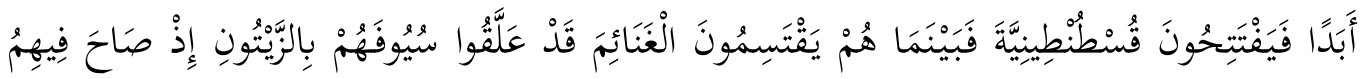

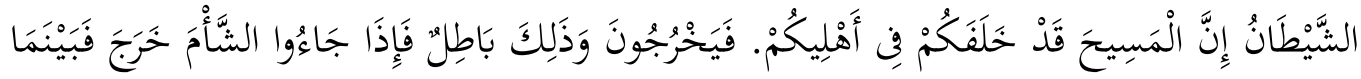

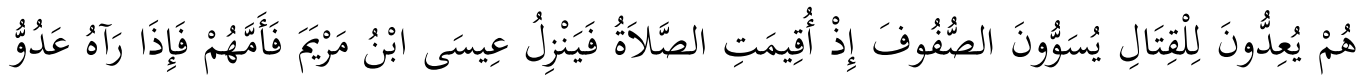

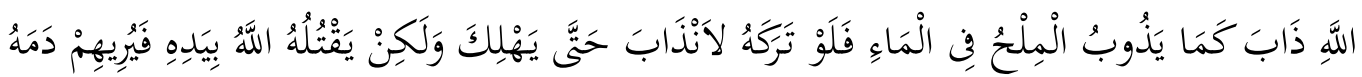
رفِ حَرْبِتَهِه 《.

"Dari Abū Hurairah, Rasulullah Saw bersabda: "Hari kiamat tidak akan terjadi hingga bangsa Romawi turun menuju Dābiq, mereka dihadapi oleh sebuah tentara dari Madinah, mereka adalah sebaik-baik penduduk bumi saat itu.... dan pada akhirnya mereka memenangkan Konstatinopel...." 40

Kekuasaan al-Mahdī berakhir dengan munculnya Dajjal begitu pula dengan 'Isa bin Maryam. Ini dapat disimpulkan dari banyak riwayat di antaranya adalah yang menyebut bahwa Nabi 'Isa nanti akan menjadi makmum bagi al-Mahdī, yang diriwayatkan dari Jābir bin 'Abd Allāh.

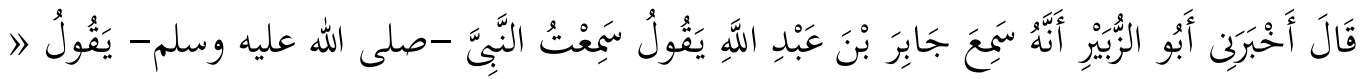

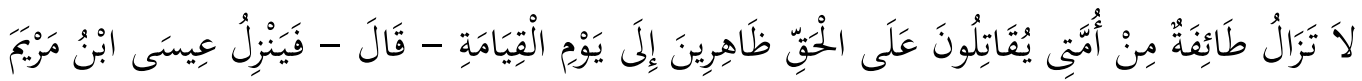

\footnotetext{
${ }^{39}$ Abū Dāwud, Sunan Abī Dāwud, juz 4,183

${ }^{40}$ Muslim bin al-Ḥajjāj, Șaḥịh Muslim, juz 8, 175.
} 


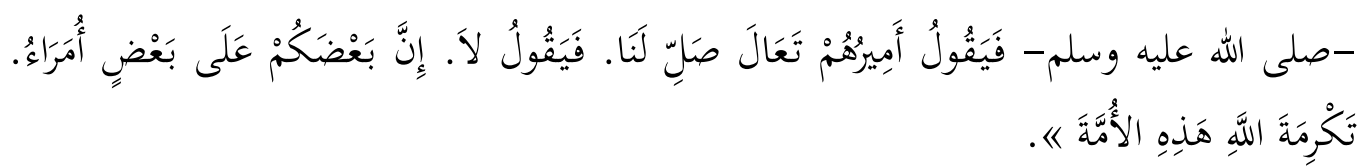

"Dari Jābir bin 'Abdillah, saya mendengar Rasulullah Saw bersabda:

"Umatku senantiasa berperang di jalan kebenaran dan mereka memenangkannya sampai hari kiamat. Kemudian 'Isa As turun. Pemimpin umat Islam saat itu meminta 'Isa untuk menjadi imam, namun 'Isa mengatakan tidak. Di antara kalian terdapat pemimpin sebagai wujud dari penghormatan Allah kepada umatnya. "4l

Setelah kemenangan atas Konstatinopel, maka muncullah Dajjal sebagaimana disebutkan dalam riwayat di atas dan di dalam banyak riwayat lain. Salah satunya adalah sebagaimana yang diriwayatkan oleh Ummul Mukminin Hafsah. $^{42}$

$$
\text { إنما يخرج الدجال من غضبة يغضبها }
$$

"Sesungguhnya Dajjal akan keluar dari sebuah kemarahan yang memancing kemarahannya." 43

Akhir dari cerita Dajjal ini nantinya berada di tangan Nabi 'Isa As, itulah mengapa 'Isa diturunkan di samping untuk alasan-alasan lain seperti sebagai Imam yang adil, memecahkan salib dan lain sebagainya. ${ }^{44}$

Hadis yang diriwayatkan oleh Khudzaifah bin Usaid menggambarkan situasi yang terjadi ketika Dajjal keluar.

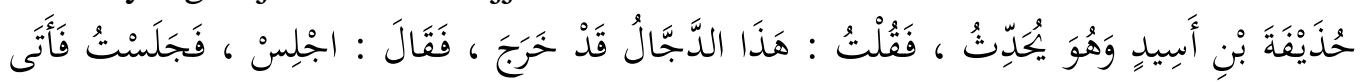

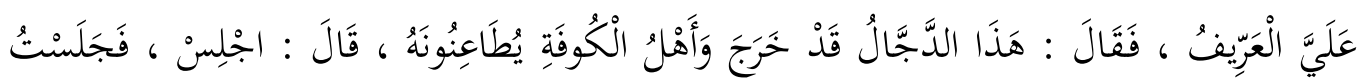

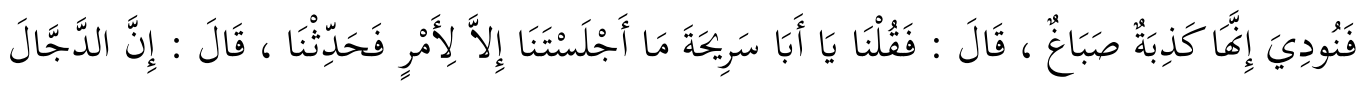

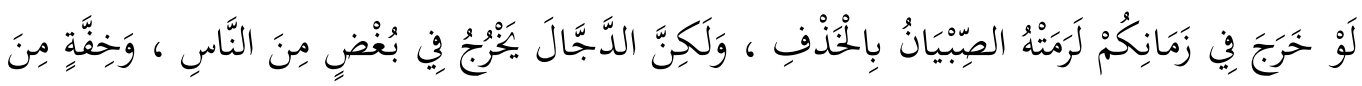

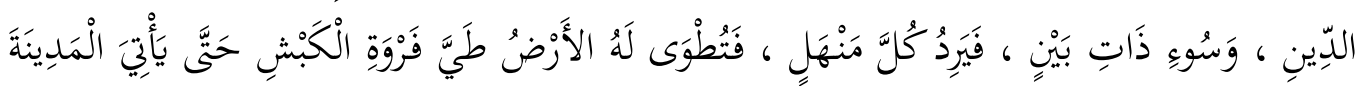

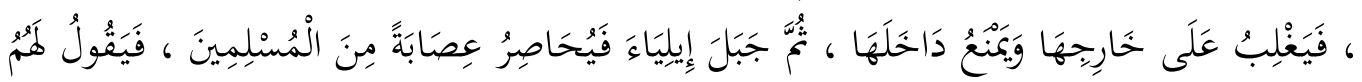

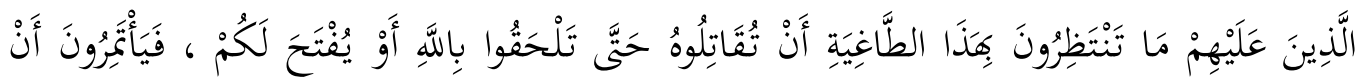

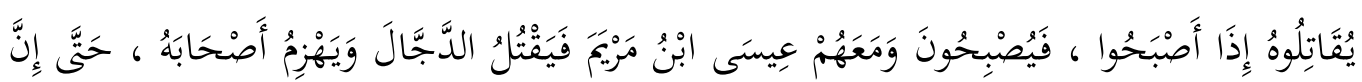

\footnotetext{
${ }^{41}$ Muslim, Șahīh Muslim, juz 1, 95.

${ }^{42}$ Yāsir bin 'A Abd al-Raḥmān al-Aḥmad̄̄, Malāhim Ākhir al-Zamān, 235.

${ }^{43}$ Ibn Hibbān, Saḥīh Ibn Hibbān, juz 15 (Muassasah al-Risalah, t.t.), 204.

${ }^{44}$ Yāsir bin 'Abd al-Raḥmān al-Aḥmadī, Malāḥim Ākhir al-Zamān, 256.
} 


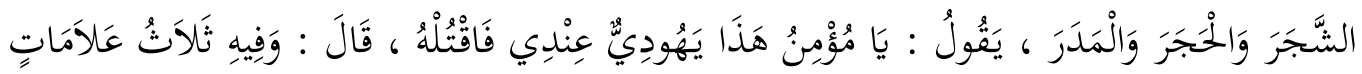

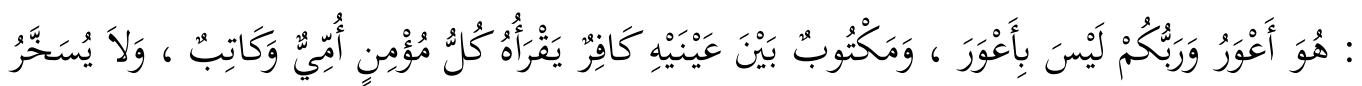

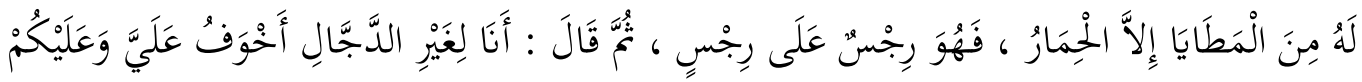

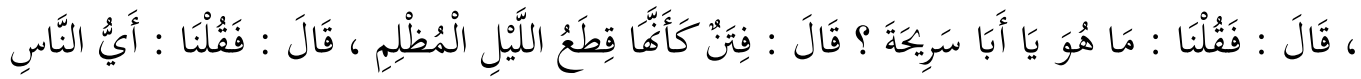

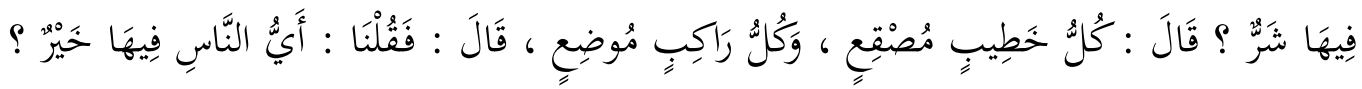

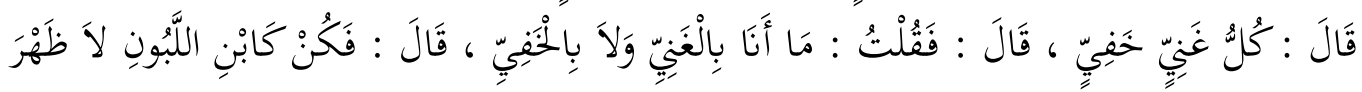

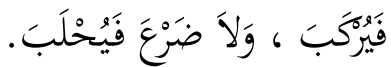

Proses pemilihan hadis-hadis di atas dalam desertasi Yāsir telah disesuaikan dengan prinsip-prinsip yang relevan seperti hanya menggunakan hadis-hadis yang shahih, melakukan proses pengumpulan hadis-hadis dalam satu tema, menyusun alur kronologis yang tepat, tidak memberikan penafsiran di luar teks dan banyak lagi yang lainnya.

Di samping itu, banyak juga ditemukan riwayat-riwayat tentang hari akhir yang bermasalah. Sebagaimana telah kami sebutkan di awal, Șalāḥ al-Dīn alIdlibī merangkum banyak riwayat yang sumbang dan tidak shahih dalam memberikan prediksi terhadap hadis akhir zaman. Ini akan kami bahas pada poin keempat makalah ini.

\section{Hadis-Hadis Bermasalah tentang Akhir Zaman}

Berikut adalah beberapa hadis yang bermasalah terkait hadis-hadis akhir zaman. Umumnya hadis semacam ini memiliki tendensi untuk mengunggulkan satu atau dua hal, seperti mengunggulkan Syam sebagai negeri yang paling diberkahi. ${ }^{45}$

Pertama adalah riwayat Imam Ahmad yang berasal dari sahabat Khuraim bin Fatik al-Asady, sebagai berikut:

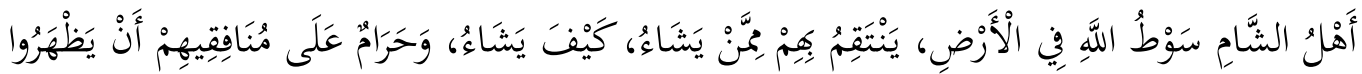

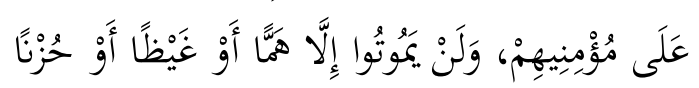

"Penduduk Syam adalah cemeti Allah di dunia, melalui mereka, (Allah) membinasakan setiap orang yang Ia kehendaki dan dengan cara yang Ia kehendaki. Diharamkan bagi orang-orang munafik untuk mengalahkan orang-orang Syam yang beriman, dan mereka (orang-orang munafik) tidak akan mati kecuali dalam keadaan gelisah, marah dan sedih."

${ }^{45}$ Șalāḥ al-Dīn al-Idlibī, Ahādīth Faḍāil al-Shām: Dirāsah al-Naqdiyyah, 2. 
Hadis dengan redaksi ini terdapat dalam "Musnad Ahmad", melalui jalur Khuraim bin Fatik. Sayangnya Syu'aib Arnauth (w. 1438 H) menilai hadis ini dhaif. Demikian pula dengan Syekh al-Albani (w. $1420 \mathrm{H}$ ) yang menilai dhaif. Studi yang lebih jauh mengenai hadis ini pernah dilakukan oleh Syekh Shalahuddin al-Idlibi. Beliau menyimpulkan bahwa redaksi ini bukanlah hadis yang riwayatnya sampai kepada Rasulullah SAW, karena hanya sampai kepada sahabat Nabi SAW yang bernama Khuraim bin Fatik al-Asady, dalam istilah ilmu hadis disebut sebagai hadis mauquf. Kesimpulan ini dapat dirujuk dalam karyanya "Ahadits Fadhail al-Syam." Adapun hasil kesimpulan Syekh al-Idlibi didapatkan dari upayanya mengumpulkan seluruh jalur periwayatan dan menganalisisnya sesuai dengan kaidah-kaidah dalam ilmu hadis. ${ }^{46}$

Dalam menilai sebuah hadis, dapat dinamakan shahih apabila bersambung sanad atau periwayatnya. Selain itu, periwayat tersebut juga harus memiliki kriteria adil dan kredibel. Syarat yang terakhir, hadis tersebut juga harus terhindar untuk dari indikasi syadz ataupun ilat (cacat). Setelah seluruh jalur periwayatan dikumpulkan oleh Syekh al-Idlibi, hadis di atas dibagi menjadi dua. Pertama adalah riwayat yang marfu' (hadis yang jalur sanadnya sampai kepada Rasulullah SAW), ini terdapat dalam "al-Mu'jam al-Kabir" karya al-Thabrani dan dalam riwayat Ibn "Asakir. Dari keduanya, ditemukan tiga jalur periwayatan yang masing-masing melalui perawi yang bernama al-Walid bin Muslim dari Muhammad bin Ayyub bin Maisarah dan seterusnya hingga sahabat Khuraim dan Nabi Muhammad SAW. Dari tiga jalur ini semuanya marfu' kepada Nabi SAW. ${ }^{47}$

Riwayat yang kedua adalah mauquf. Riwayat ini ditemukan dalam empat tempat, di dalam "Tarikh Dimasyq" karya Ibn "Asakir, "al-Ahad" karya Ibn Abi "Ashim, "al-Ma'rifah wa al-Tārìkh" karya Ya'qub bin Sufyan, dan "al-Tsiqat" karya Ibn Hibban. Kempatnya meriwayatkan melalui jalur yang sama dengan riwayat marfu' sebelumnya, yakni melalui al-Walid bin Muslim dari Muhammad bin Ayyub bin Maisarah dan seterusnya, tetapi tidak sampai kepada Rasulullah SAW.

Jalur riwayat marfu' yang berasal dari al-Walid bin Muslim di atas sepertinya tidak terlihat ada masalah, namun jika dibandingkan dengan riwayat yang kedua, tampat jelas bahwa sebenarnya riwayat al-Walid bin Muslim dari Muhammad bin Ayyub ternyata mauquf. Dalam istilah ilmu hadis, fakta ini disebut dengan ilat (cacat), yakni hadis yang kelihatannya shahih namun ternyata ditemukan suatu sebab yang samar dan tersembunyi (dalam hal ini terputus hanya sampai sahabat) yang menyebabkan rusaknya hadis tersebut. Ilat yang dimaksud adalah memarfu'kan hadis mauquf. Oleh sebab itu Syekh al-Idlibi menyimpulkan bahwa hadis dengan riwayat marfu' di atas lemah atau dhaif.

\footnotetext{
${ }^{46}$ Șalāḥ al-Dīn al-Idlibī, Ahāōìth Faḍail al-Shām: Dirāsah al-Naqdiyyah, 32.

${ }^{47}$ Maḥmūd al-Ṭahān, Taisìr Muștalah al-Hadīts, 30.
} 
Kedua, hadis yang diriwayatkan dari 'Abdullah bin 'Amr bin 'Ash, sebagai berikut:

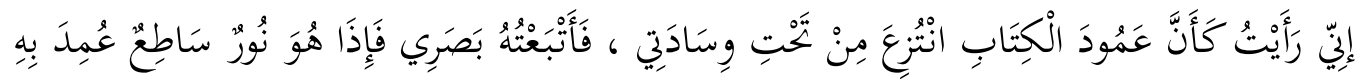

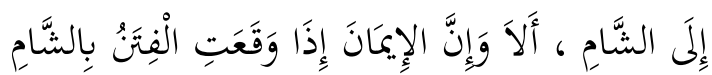

"Sesungguhnya aku bermimpi seakan-akan penopang al-kitab ditarik dari bawah bantalku, maka aku ikuti kemana ia dibawa, dan tiba-tiba ada cahaya yang bersinar membawanya pergi ke Negeri Syam, ingatlah bahwa iman akan berada di Syam ketika terjadi banyak fitnah."

Menurut Ibn Taimiyyah yang dimaksud dengan penopang al-kitab ('amud al-kitab) atau bisa juga disebut dengan penopang Islam ('amud al-Islam) adalah sesuatu yang dijadikan pegangan, yang dipegang oleh orang-orang yang membawanya. Komentar lain terkait hadis di atas juga muncul dari 'Izzuddin bin 'Abd al-Salam dalam karyanya Targhib Ahl al-Islam fi Sukna al-Syam, menurutnya, yang dimaksud oleh Nabi dengan 'amud al-Islam, bahwa ketika terjadi fitnah saja orang-orang Syam adalah orang-orang yang selalu menetapi keimanan, mereka tetap berpegang teguh dengan keimanan mereka, lantas bagaimana ketika mereka tidak ditimpa fitnah? Mereka tentu akan jauh lebih beriman kepada Allah. Bagi Syekh 'Izzuddin, hadis ini memberikan pujian yang sangat tinggi bagi penduduk Syam yang memiliki keimanan yang sangat tinggi dan istimewa.

Hadis yang bersumber dari 'Amr ibn 'Āṣ di atas dapat dijumpai dalam kitab al-Mustadrak karya al-Hakim. Menurut al-Albani hadis tersebut shahih. Meskipun al-Albani menganggapnya shahih, namun terdapat kritik terkait hadis ini dari Syekh al-Idlibi. Ia mengumpulkan seluruh jalur periwayatannya dan menganalisis kualitasnya dari sudut pandang sanad dan matan hadisnya. ${ }^{48}$

Hadis di atas diriwayat oleh beberapa sahabat, di antaranya adalah Abu Darda', 'Abdullah ibn 'Amr, 'Umar ibn al-Khaththab, Abū Umamah, 'Aisyah, 'Amr ibn 'Āṣ, 'Abdullah ibn 'Umar dan riwayat mursal dari Abū Qilabah. Dari seluruh sanad yang ada tidak ada satupun sanad yang shahih, semua sanadnya dhaif. Terutama hadis mursal yang hanya sampai kepada tabi'in, maka dia dianggap hadis dhaif, umumnya hadis semacam ini bukan disebut dengan hadis, namun disebut dengan atsar, atau khabar.

Dari sudut pandang matan (isi hadis), menurut Syekh al-Idlibi, matan hadis di atas terkesan sumbang, pasalnya bagaimana mungkin 'amud al-kitab, yang dalam hal ini adalah Alquran diambil dari bawah bantal kenabian dan dibawa ke Syam, bukan ke seluruh penjuru negeri, mengingat Alquran dan Nabi Muhammad adalah wahyu dan Nabi yang terakhir yang diutus untuk seluruh alam. Ini menunjukkan seakan-akan Syam yang menjadi tempat berlindung para nabi

${ }^{48}$ Șalāḥ al-Dīn al-Idlibī, Ahâàìth Faḍāil al-Shām: Dirāsah al-Naqdiyyah, 22. 
sebelumnya tidak ada bandingannya dengan Mekah dan Madinah. Lantas bagaimana dengan Mekah dan Madinah? Ketika terjadi fitnah, keimanan hanya berpusat di Syam, bukan yang lainnya? Padahal faktanya, umat Islam memusatkan seluruh perhatiannya sampai saat ini kepada Mekah. Oleh sebab itu, tidak akan berpengaruh sama sekali banyaknya riwayat dhaif terhadap hadis ini, karena hadis ini sumbang (munkar) secara matan.

Berbicara tentang muara keimanan di akhir zaman, Mekah dan Madinah memiliki banyak keutamanaa yang lebih mentereng di akhir zaman di bandingkan dengan Syam. Kualitas hadis-hadisnya pun lebih kuat dibandingkan dengan hadis-hadis Syam. Hal ini bisa dilihat dari banyaknya hadis-hadis yang secara spesifik menyebutkan Mekah dan Madinah berikut.

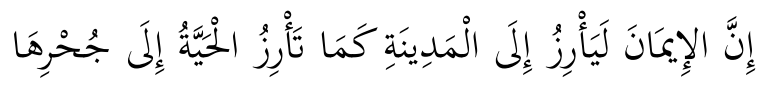

"Sesungguhnya keimanan akan bersarang ke Madinah sebagaimana ular bersarang ke dalam lubangnya (sarangnya)."

Ketiga, hadis yang diriwayatkan dari Abu Darda', bahwa Rasulullah SAW bersabda:

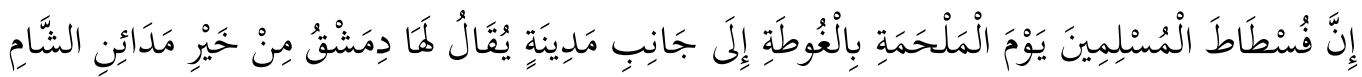

"Sesungguhnya barak kaum muslimin di hari perang besar terjadi berada di Ghauthah (nama sebuah daerah di Syam), sampai ke sisi sebuah kota yang dinamakan Damaskus, kota terbaik dari kota-kota yang ada di Syam."

Hadis ini memiliki maksud bahwa ketika terjadinya perang besar (maqtalah udzma), benteng terakhir umat Islam saat itu adalah kawasan Ghauthah, nama sebuah tempat di Syam. Tempat tersebut penuh dengan air dan pepohonan. Beberapa pendapat mengatakan bahwa perang besar yang dimaksud adalah perang besar yang terjadi antara umat Islam dan tentara Salibis.

Hadis ini terdapat dalam Sunan Abu Dawud, yang dinilai shahih oleh alAlbani dan juga Yahya bin Ma'in, yang mengatakan bahwa tidak ada hadis-hadis yang berbicara terkait negeri Syam yang paling shahih selain hadis tentang perang besar ini. Namun perbedaan pendapat diutarakan oleh Syekh al-Idlibi, dalam kitab anggitannya Ahadīts Fadhail al-Syam: Dirāsah Naqdiyyah (Hadis-Hadis Keutamaan Syam: Studi Kritis),hadis ini berstatus dhaif. Kesimpulan ini didapatkan setelah mengkaji seluruh jalur periwayatannya. ${ }^{49}$

Beberapa sahabat yang meriwayatkan hadis ini, di antaranya adalah Abu Darda', 'Auf bin Malik, Mu'adz bin Jabal, dan beberapa sahabat lainnya. Hadis ini memiliki syahid (jalur pendukung lain) yang bersumber dari Abū Hurairah dan dari riwayat mursal Abū Zahirah dan 'Ali Zainal 'Abidin. Hadis yang bersumber dari Abū Darda' pada dsarnya berkualitas shahih, sayangnya setelah ditelusuri terdapat riwayat lain yang menyebutkan bahwa Abū Darda' dalam riwayat tersebut tidak ada dan hanya sampai ke tabi' in yang bernama Jubair bin Nufail,

${ }^{49}$ Șalāḥ al-Dīn al-Idlibī, Ahāàìth Faḍaìl al-Shām: Dirāsah al-Naqdiyyah, 17. 
dengan begitu riwayat kedua ini mursal. Fakta ini membuat riwayat Abū Darda' memiliki 'illat dan tidak lagi dianggap shahih, namun dhaif.

Hadis berikutnya yaitu hadis dari 'Auf bin Malik, hadis ini hadis yang dhaif. Kemudian hadis dari Mu'ad bin Jabal di dalam riwayatnya terdapat seorang rawi yang dituduh sebagai seorang pendusta atau dalam studi hadis dikatakan sebagai muttaham bil kadzb. Adapun beberapa riwayat pendukung dari Abu Hurairah ternyata jalur periwayatannya sangat lemah atau dhaif jiddan. Dan riwayat Abu Zahirah dan 'Ali Zainal Abidin keduanya adalah riwayat mursal, maksudnya hanya sampai kepada tingkat tabi' in. Oleh sebab itu riwayat tersebut tidak bisa dikatakan sebagai hadis yang bersumber dari Nabi SAW, melainkan hanya sebagai atsar atau khabar saja.

Sepanjang sejarah, Syam pernah mengalamai tiga perang besar, yaitu perang Yarmuk, perang 'Ain Jaluth, dan perang Haththin. Perang Yarmuk terjadi antara umat Islam dan kekaisaran Bizantium, yang berhasil dimenangkan oleh umat Islam. Selanjutnya adalah perang 'Ain Jalut dengan bangsa Tartar atau Barbar, perang ini juga yang dimenangkan oleh umat Islam, dan menghentikan ekspansi mereka ke negeri-negeri Islam lainnya. Dan yang terakhir adalah perang Haththin antara umat Islam dan tentara salibis yang juga dimenangkan oleh umat Islam.

Jika yang dimaksud dalam hadis prediktif di atas adalah tiga perang besar di atas, maka periode prediksi hanya akan berakhir pada tiga perang tersebut dan tidak lagi bisa ditarik ulur ke belakang. Apalagi ditafsirkan secara sembarang dan digunakan untuk melegitimasi kekacauan yang tengah terjadi di wilayah bekas Syam saat ini, atau yang secara khusus terjadi di Suriah.

Begitu juga dengan hadis-hadis prediksi lainnya, ketika yang dikehendaki oleh Nabi Muhammad adalah suatu hal yang khusus, maka setelah hal khusus itu berakhir, maka berakhirlah periode prediksi tersebut. Dalam sebuah riwayat dari Abu Hurairah RA, Rasulullah SAW bersabda:

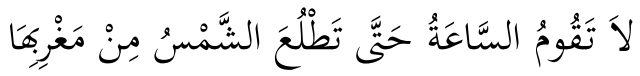

"Hari kiamat tidak akan terjadi sampai matahari terbit dari barat."

Hadis ini menjelaskan tentang fenomena yang akan terjadi di akhir zaman, bahwa akan terjadi suatu fenomena di mana matahari yang biasanya secara hukum alam terbit dari timur dan menuju ke barat, ia akan berubah kebalikannya yakni, dari barat ke arah timur. Ketika peristiwa ini belum terjadi, maka hadis prediktif tersebut masih tetap akan berlaku, dan akan berakhir ketika ia telah terjadi.

Keempat, Terdapat sebuah hadis yang diriwayatkan oleh Salamah bin Nufail al-Kindi, ia mengatakan bahwa suatu ketika ia pernah duduk-duduk bersama Rasulullah SAW. Tiba-tiba seorang laki-laki datang dan mengatakan, "Wahai Rasulullah orang-orang telah memarkirkan kuda mereka, meletakkan senjata mereka, dan mereka mengatakan bahwa tidak ada lagi jihad dan perang telah usai." Kemudian Rasulullah SAW menghadapkan wajahnya, dan 
mengatakan, "Mereka telah berdusta, sekarang, sekarang, perang telah dimulai, senantiasa umatku berperang di atas kebenaran, Allah menyesatkan hati beberapa kaum, dari mereka Allah memberikan rezeki kepada umat Islam (berupa rampasan perang) sampai datangnya hari kiamat. Kuda saat itu telah diikat dan di setiap jambulnya terdapat kebaikan sampai hari kiamat tiba,..." kemudian Rasulullah mengatakan:

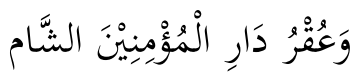

"Dan Syam adalah bagian utama rumah orang-orang beriman."

Kata 'Uqr dalam kalimat di atas bisa diartikan sebagai pangkal, pokok, atau inti. Dalam bahasa Arab, 'uqr al-kal'a atau 'uqar al-kal'a berarti bagian terbaik dari tanaman yang dipelihara. Atau seperti dalam kalimat hadza al-bait 'uqr alqashidah, artinya adalah bait atau sajak yang terbaik. Jadi bisa diartikan pula bahwa 'uqr atau 'aqar adalah bagian terbaik dari segala sesuatu.

Hadis di atas dapat dijumpai dalam Sunan al-Nasa'i. Secara kualitas hadis di atas dianggap shahih oleh al-Albani. Namun, kesimpulan berbeda diutarakana oleh Syekh al-Idlibi dalam Ahadits Fadhail al-Syam: Dirasah Naqdiyyah (HadisHadis Keutamaan Syam: Studi Kritis). Kajiannya terhadap hadis di atas diambil setelah mengumpulkan seluruh jalur periwayatan dengan mengkritik sanad hadis di atas.

Hadis di atas dapat dirujuk di berbagai kitab, di antaranya adalah di dalam Mu'jam al-Kabīr, Sunan al-Nasā'i, Musnad al-Syamiyin, al-Ahad wa al-Matsani, Tarīkh Dimasyq, dan lain sebagainya. Seluruhnya diriwayatkan melalui tiga rangkaian sanad, dari al-Walid bin 'Abdurrahman, dari Jubair bin Nufair, dari Salamah bin Nufail dan dari Nabi SAW. Baik al-Walid maupun Jubair tercatat adalah dua orang perawi yang tsiqah. Namun tidak dengan Salamah bin Nufail. Tidak ada kesepakatan terkait biografi Salamah bin Nufail, Abu Hatim dan alBukhari menyebut bahwa dia pernah menemani Nabi (red. Lahu suhbah), dari redaksi ini tampak ada keraguan atau ketidak pastian terkait kebenaran bahwa dia adalah sahabat Nabi yang dihukumi adil. Dalam Sunan al-Nasa'i disebutkan bahwa dia tidak meriwayatkan hadis kecuali satu, hadis yang dimaksud adalah inni ghair labitsin fikum illa qalill (saya tidak tinggal bersama kalian kecuali sebentar). Di dalam al-Ishabah fi Tamyiz al-Shahabah, Ibn Hajar menyebutkan bahwa Salamah pernah tinggal di Hamsh, salah satu daerah di Syam.

Karena alasan di atas, Syekh al-Idlibi menganggap bahwa tidak ada kesepakatan secara mutawatir bahwa Salamah bin Nufail adalah sahabat Nabi, tidak ada berita yang santer baik itu melalui istifadhah, syuhrah atau melalui kabar para sahabat lain yang menyebutkan bahwa dia adalah sahabat Nabi. Kabar yang mencuat terkait posisinya sebagai sahabat Nabi tidaklah muncul kecuali dari dirinya sendiri yang meriwayatkan hadis tersebut di atas, bahwa dia pernah bersama-sama Nabi dan sahabat Nabi lainnya. Hal ini tentu saja tidak bisa diterima kecuali keadilannya sudah teruji sebelum kabar tersebut muncul, juga 
tidak ada ulama yang memberikan komentar terkait keadalahannya. Ini membuktikan bahwa Salamah bukanlah sahabat Nabi yang telah pasti dianggap adil oleh mayoritas ulama. Karena alasan tersebut, maka Syekh al-Idlibi menganggap bahwa hadis di atas dianggap memiliki sanad yang lemah, dan bisa jadi hadis tersebut tidak benar berasal dari Nabi Muhammad SAW. ${ }^{50}$

\section{Kesimpulan}

Dari kajian ini dapat disimpulkan bahwa beberapa hadis yang berkaitan dengan akhir zaman masih diperhitungkan menurut Ahlussunnah wal Jamaah. Dalam beberapa kasus, Di antara hadis Ahad dan Israilliyat mereka memilih hadis Ahad tentu disertai dengan pertimbangan kualitas hadisnya. Adapun untuk melihat maksud dari suatu hadis, Ahlussunnah wal Jamaah menggunakan tujuh tahapan yang tertera dalam pembahasan di atas.

\section{Daftar Pustaka}

Abdillah, Junaidi. "Studi Kritik Melalui Metode Takhrij Hadits Tentang Menghias Bangunan Masjid Sebagai Tanda Akhir Zaman." Jurnal Al Ijtimaiyyah 4, no.1 (2018): 26-63.

Abdullah, Taufik dan Abdurrachman Surjomihardjo (Ed.). Ilmu Sejarah dan Historiografi: Arah dan Perspektif . Jakarta: PT Gramedia, 1985.

Al-Aḥmadī, Yāsir bin 'Abd al-Raḥmān. Malāḥim Ākhir al-Zamān. Riyadh: Maktabah Majallah al-Bayān, 1434.

Al- 'Alwān̄̄, Țahā Jābir. Ishkāliyyat al-Ta'āmul Ma'a al-Sunnah al-Nabawiyyah . Virginia: al-Ma'had al-'ālami li al-Fikr al-Islāmī, 2014.

Al-Bukhārī. Șah̄ịh al-Bukhārī. Kairo: Dār al-Sya'b, 1407.

Che' Had, Soleh bin. "Penafsiran Ayat Tentang Hari Kiamat Menurut Umar Sulaiman "Abdullah Al-Asyqar." Universitas Islam Negeri Ar-Raniry, 2018.

Al-Dānī, Abū 'Amr. al-Sunan al-Wāridah fì al-Fitan wa Ghawā'iluhā wa alSā'ah wa Ashrātuhā. t.k: Rị̣ā Allāh al-Mubārakfurī. Dār al-'āṣimah, t.t.

Al-Daurā, 'Abd al-'Azīz. Nasy'ah 'Ilm al-Tārīkh 'ind al- 'Arab. t.k: t.p, t.t.

Dliyauddin, Muhammad, "Hadith Prediktif Perang Melawan Bangsa 'Ajam yang Bermata Sipit Sebagai Tanda Hari Kiamat." Universitas Islam Negeri Sunan Ampel, 2018.

Hadiyanto, Andy dan Umi Khumairoh. "Makna Simbolik Ayat-Ayat tentang

Kiamat dan Kebangkitan dalam Alquran." Indonesian Journal of Multidisciplinary Islamic Studies 2, no. 2 (2018).

Al-Hajjāj, Muslim Ibn. Șaḥịh Muslim. Beirut: Dār al-Jail, t.t.

Hanbal, Ahmad Ibn. Musnad Ahmad. Beirut: 'Ālam al-Kutub, 1419.

Hibbān, Ibn. Șah̄ịh Ibn Hibbān. Muassasah al-Risalah, t.t.

Al-Ishbilī. al-Aḥkām al-Syar'iyyah al-Kubra. Riyāḍ: Maktabah al-Rushd, 2001.

${ }^{50}$ Șalāḥ al-Dīn al-Idlibī, Ahāàìth Faḍail al-Shām: Dirāsah al-Naqdiyyah, 49. 
Mājah, Ibn. Sunan Ibn Mājah. Maktabah Abi al-Ma'āṭ̂̄, t.t.

Al-Munajjid, Muḥammad Șāliḥ. Tūūbā li al-Shām. Riyāḍ: Majmū'ah al-Zād li alNashr, 2015.

Al-Muqaddim, Muhammad bin Aḥmad. Fiqh Ashrāṭ al-Sä'ah. Iskandariyah: alDār al-'ālamiyyah li al-Nashr wa al-Tauzī', 2008.

Pane, Akhiril. "Urgensi Bahasa Arab; Bahasa Arab Sebagai Alat Komunikasi Agama Islam.” Komunikologi 2, no. 1 (2018).

Al-Qarḍāwī, Yūsuf. Kaifa Nata 'āmal ma'a al-Sunnah al-Nabawiyyah. Kairo: Dār al-Syurūq, 2004.

Riḍā, Muḥammad Rashīd. Tafsīr al-Manār. Beirut: Dār Kutub al-Ilmiah, 1999

Șalāḥ al-Dīn, Al-Idlibī. Ahâadìth Faḍāil al-Shām: Dirāsah al-Naqdiyyah. t.k: t.p, t.t.

Al-Sijistān̄̄, Abū Dāwud Sulaimān. Sunan Abī Dāwud. Beirut: Dār al-Kitāb al'Arabī, t.t.

Al-Ṭaḥhān, Mạ̣mūd. Taisīr Muștalah al-Hadīth. Beirut: Dār al-Fikr, t.t.

Al-Tirmidzī. Sunan al-Tirmidzī. Beirut: Dār Iḥyā' al-Turāth al-'Arab̄i, t.t.

Yatim, Badri. Perkembangan Historiografi Islam. Ciputat: Lembaga Penelitian UIN Jakarta, 2009.

Al-Żahabī, Shams al-Dīn. Siyar A 'lām al-Nubalā'. Beirut: Muassasah al-Risālah, 1405. 